\title{
Advantages and disadvantages of knowledge and wisdom
}

\author{
Mohammad Ali Hosseini \\ Department of Social Sciences, Payame Noor University, P.O. Box 19395-3697, Tehran, Iran \\ Email:m_hosseini2004@yahoo.com
}

\begin{abstract}
When a person is born, apart from natural instincts and biological impulses endowed in his existence, is unaware of realities around him. He gets acquainted with the world around him by utilizing senses and wisdom bestowed upon him by God. With the passage of time he understands realities of the World. The wisdom plays the role of the lamp and with its light removes ignorance and darkness and introduces new horizons of secrets of universe to him. Knowledge becomes instrument of dynamism and development of human-being. With increase in knowledge, ignorance changes into information and darkness into light and shows the way to highest achievements. Even knowledge itself becomes an achievement for human soul and as stated by eminent Philosopher, Mulla Sadra, the human soul develops existence in the light of knowledge and attains heights.
\end{abstract}

Keywords: Results, Fruits, Knowledge, Wisdom, Material, Spiritual.

\section{Introduction}

The subject of discussion is traces and outcome of knowledge, results are so evident, that even ignorant people are aware of it. These can be divided into two major groups: 1- Material vestiges and results 2- Spiritual traces and results. The material outcome of knowledge does not need any explanation and is quite visible in everyday life, starting from writing and reading a letter and traversing into the world of scientific, industrial and technological advances of contemporary world. All this is indebted to material achievements of knowledge and wisdom of scientists.

It is in the shadow of scientific progress that various societies and governments have gained strength and have attained comparative superiority to others. So our aim is to highlight spiritual outcome of knowledge and wisdom. It is to be dealt with in two parts:

\section{Results and fruits of knowledge and wisdom}

\subsection{Spiritual outcome of knowledge}

Knowledge leaves very deep impressions on the soul of human being the results of which are reflected in external and internal acts. Some of these are:

(1) Recognition of Al-Mighty God: Those who are more acquainted with the secrets of creation, realizes the greatness of creater more than others, hence Hadrat Ali (A.S.) said: 《ثمرة العلم معرفة الله. [1, Vol.3, Page 322].

(2) Faith: Knowledge is one of the Pre-requisite for faith. Without awareness, faith is not accomplished. Emam Ali (A.S.) has said "Faith and Knowledge are twin brothers and friends and are inseparable.

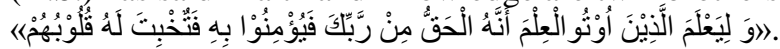

Al-Mighty God refers to the same in SURA-HAJ-Verse 54 [1, Vol.2Page 47].

"And that they who have been given knowledge may know that it is the truth from Thy Lord and believe in it, and so their hearts he humble unto Him..."

(3) Fear of God: Knowledgeable Scholars realize the greatness of God more than others, and this increase their love for God and fear for His Wrath. God reveals in Verse 28 of Sura FATER,

《.إنما يخشي اله من عبادهِ العلماء [1, Vol.2, H 1785 Page 47].

"Only Wise people have fear of God" Hadrat Ali (A.S.) also has said «اعلم الناس باله أخوفهم منه. [1, H-3123, Vol.2 - Page 423 and H3157 Vol.2, Page 430] 
or «أكثر هم خشيئة له. [1, H-3123, Vol.2 - Page 423 and H 3157 Vol.2, Page 430].

"By God, most wise are those who fear God - more".

(4) Worship of God: When a person recognizes his creater through studies of secrets of creation and understands the unlimited blessings given by the creater, he naturally bows down before him. Hadrat Ali (A.S.) remarks,

"The result of knowledge is worship" [1,H 6357 Vol.4, Page 370]

(5) Abstention from Moral Degradation: One who is aware of evil and moral degradation will never allow him to fall in The trap which has nothing but harm and loss. In view of this Hadrat Ali (A.S.). Consider Jealousy, envy and avarice as outcome of ignorance. 《الحرصنُ و الشرهُو البخلُ نتيجةُ الجهل [1, Vol.2, Page 28, H-1694].

"Jealousy, Envy and Avarice are results of ignorance".

(6) Improvement and Correction of Self: Emam Ali (A.S.) says "As the knowledge of Man increases, he attends more to his "self" and tries more to correct himself and devotes more to inner development" [1, H-7204, Vol.4, Page 621].

(7) Discipline and Humility viz-a-viz God and His Creation: A person who knows that he has nothing of his own and everything he has, has been given by God and he is an humble being amongst creation of God, necessarily bows

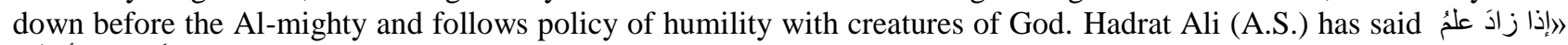
[1, Vol.3, Page 193, H-4175].

"Discipline of a Person increases with the increase in knowledge".

(8) Guidance of Man towards Truth: Says Hadrat Ali (A.S.)

《1, Vol.2, Page 7, H-1581].

(9) Non-attention to Mortal World: Says Hadrat Ali (A.S.)

《.ثمرة المعرفة العزوفُ عن دارِ الفناءِئ [1, Vol.3, Page 333, H-4651].

The first of tree of knowledge is Non-attention and detachment from mortal world.

(10) Value of Action and worship of Human Being: Says Hadrat Emam Kazem (A.S.)

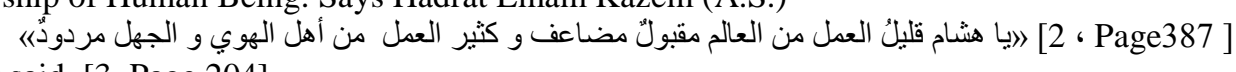

Hadrat Ali (A.S.) in a statement said, [3, Page 204].

"A worshipper without knowledge is like an animal mover of the Stone Wheel, who moves regularly on a set orbit and does not step forward".

(11) Patience against Hardships: Emam Ali (A.S.) says:

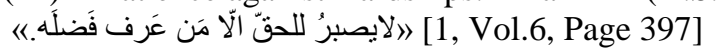

They do not tolerate Truth unless they believe in its superiority.

(12) The Guide to Wisdom: The Prophet (PBUH) says:

《2, Page 28].

Knowledge is a guide to wisdom.

(13) Social Awakening and Resistance against doubts and Satanic instinct: Emam Sadeq (A.S.) said, 《 [4, Vol.I, Page 26].

One who is aware of his times, does not fall prey to suspicion and does not follow wrong path.

\subsection{Spiritual traces of wisdom}

Outcome of Wisdom: Wisdom has two meanings:

(1) Source of abstention from foolish and bad acts.

(2) Firmness and Strength: Hence it is considered that wisdom is based on knowledge and is void of folly and so knowledge stemming from wisdom is free from decay. The wisdom can be interpreted in the following manner on the basis of sayings of the Prophet (PBUH) and commentaries "Wisdom is Scientific, Practical and Spiritual pre-requisite for man to attain the high goal" so wisdom can be defined in two ways (1) Theoretical Wisdom (2) Practical Wisdom Man by learning theoretical wisdom and absorbing practical wisdom in his acts creates scope for creation of the reality of light of wisdom in his heart and this is the light which God had kindled in the hearts of human beings. As much the heart is illuminated with this, lust and wordly avarice vanishes, yielding place to the wisdom and leading the person towards high human objectives [5, Page 44, Page 44].

Based on some fables and traditions, wisdom has following results:

1. Reduction of Lust: Emam Ali (A.S.) says "Lust is weakened in proportion to degree of strength of wisdom [1, Vol, 7205, Vol.4, Page 622].

2. Safeguard against bad and ugly: Emam Ali (A.S.) says "Human beings have bad and ugly elements in them, it is wisdom which checks it and saves them". [1, , Vol.5, Page 32].

3. Chastity: Emam Ali (A.S.) says, "Wisdom is twinned with chastity" [1, Vol.5, Page 32] Wisdom being twinned with chastity does not necessarily mean that all "Non-innocents" are not wise. It is to convey that it is in relationship and proportion with the amount of Light in the human heart and the degree of chastity depends on this proportionately.. 
4. Enlightenment of Heart: Emam Kazem (A.S.) says, "God has created hearts of the believer with faith in them, so whenever decides to enlighten them, sprinkles the water of wisdom on them and sows the seeds of wisdom therein, the cultivater and preserver is the God" [4, , Vol.2, Page 421].

5. Guidance: Emam Ali (A.S.) says, "Knowledge helps and wisdom shows the truth". [1, Vol.2, Page 39].

6. Knowledge: Emam Ali (A.S.) says, "Knowledge is the outcome of wisdom and righteousness are its branches". [1, Vol.2, Page 39].

\section{Disadvantages and dangers of knowledge}

Knowledge is one of the finest gifts of Al-mighty God to human being. Human being can reach the Zenith of humanity by its correct and proper utilization and make use of it as a stepping stone for progress and development. But its misuse can be dangerous and can lead to decay and down fall of humanity. Some times before the luster of knowledge and wisdom in the hearts of people, the life was dark.

The awareness of these dangers and obstacles enables us to take precaution against them and make desirable use of this Divine gift. In this brief discussion, some of these obstacles are detailed on the basis of sayings of Innocent Emams (A.S.) and other religious elders.

\subsection{Kinds of obstacles and dangers of knowledge}

These can be divided in three parts:

(1) Obstacles and dangers which are created by learning classical knowledge such as Jurisprudence, Principles and all other Practical Sciences. Suppose, Shyness, "One who is shy, his knowledge remains little" Emam Sadiq (A.S.) [4, Vol.2, Page 106].

Lack of understanding - Hadrat Ali (A.S.) has said, "Knowledge is not acquired by luxury" [1, Vol.6, H 10684, Page 387].

(2) Obstacles and hinderances which hinder recognition of Wisdom and heart, such as recognition of God and acceptance of His Unity, for example wonder, prejudice and oppression etc. These elements hinder ideas and thought from realizing Truth and deprive heart from divine blessings and revealations.

(3) Obstacles on way to real knowledge or light of wisdom, the same knowledge which God puts into the hearts as He wishes and this is not attained by learning and thinking, it is only and only gifted by God. These obstacles again fall in two categories:

1. Veil of Darkness (Sins): They make heart dark and black and make the spirit sick and deprive human being of real knowledge, even if he is well versed in official and traditional Sciences and Knowledge.

2. Enlightened Veil - Veils and curtains which are themselves from the segment of light and are related to that world. In the supplications chanted during Nights these have been called 'Veil of Light'. [5, Page 97].

The light of sun is a hinderance in seeing the reality and the centre of the sun, though it is in itself light and source of light. So lighted veils are there which hinder understanding of reality of existence.

Hadrat-e-Emam (RH) while explaining this hinderance says, "Attention to other them God, makes man victim to Dark and lighted veils and curtains. If one concentrates on all wordly affairs and ignores God, dark curtain overtakes him. If world is a means to attend to Truth and the world hereafter, dark veils are changed into lighted veils, the height is that point where both veils of Darkness and veils of light are torn and drawn aside and this is The point where one enters The Divine citadel which is a rich treasure house of greatness." [6, Page 30].

The above mentioned obstacles and dangers mostly relate to second and third category of Sciences, though some of the dangers are related to all branches of knowledge and divert the world from right to wrong path and deprive it from life giving sun rays.

\subsection{Obstacles and dangers wisdom}

1. People and Lust: Hadrat Ali (A.S.) has said, "Wisdom and Lust do not live together in one heart" [1, Vol.6, Page 436].

2. Love for temporal world: Hadrat Ali (A.S.) has said, "Love for material world spoils wisdom and stops the heart from listening to words of wisdom and has painful punishment". [1, Vol.3, Page 397].

Love for material world and hankering after it is considered one of the biggest hurdles on way to attainment of light of knowledge and dangers to know Sciences. A heart a filled with love for temporal world never opts for wisdom and Divine knowledge. A worldly person learns to serve his worldly aims, and even if such a person learns about unity of

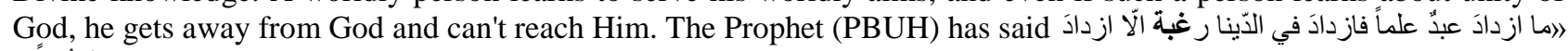
《.اً. [7, Vol.2, Page 38,]. 
A person, may increase his wisdom as far as he can, but later gets attracted to the temporal world, he moves away from God.

This learned person moves on path to hell. Hadrat Emam Khomeini Warns Students and says:

"Be careful lest you may spend 50 years more or less in Houzeh and with all efforts achieve hell" [6, Page 23].

If knowledge is controlled by wordly people and world lovers, they will commit worst type of crimes and sins by using or misusing it as it has happened in the World. In the contemporary world knowledge and scholars have been manipulated by world power mongrers who have created tragedies for humanity all over the globe. Its known example is Second World War and atomic bombing of two cities of Japan and Killing of thousands of innocent people.

3. Sin: The Prophet (PBUH) has said, "A person commits sin, no forgets the knowledge he knew earlier" [8, Page 197].

4. Heart Disease, cruelty, divisions and differences, jealously etc. Emam Hadi (A.S.) has said, "Wisdom in corrupt people does not do any good". [9, - Page 311].

5. Negligence: Hadrat Ali (A.S.) has said, "One who neglect, remains ignorant". [1, Vol.5, H1686, Page 144] "One who is overtakenly negligence, his heart dies away" [1, Vol.3, H8430, Page 293].

6. Desire: The Prophet (PBUH) said, "One who is attached to the World and prolongs his desire there in, God blinds his heart to the same proportion." [2, Page,60].

7. Arrogance and Pride: Arrogance and Pride are also dangers and deprives a person from attaining more knowledge and such a person suffers from superiority complex and does not reach any where near reality and truth. Emam Kazem (A.S.) has said, "cultivation blooms in plain and not in rocks and rocky soil; similarly wisdom flourishes in humility and humble heart and not in the heart of arrogant people [2, Page 396].

8. Avarice: The Prophet (PBUH) has said, "Avarice removes wisdom from hearts of People" [10, Vol3, Page 495].

9. Anger: Hadrat Emam Sadeq (A.S.) has said, "Anger destroys the heart of wise men, one who does not have control over his anger, is not master of his wisdom" [3,Vol.2, Page 305].

10. Prejudice: The Prophet (PBUH) has said, "Anyone who has slightest prejudice, will be put by God on dooms day amongst Arabs of Jahiliyat days". [3,,Vol.2, Page 308].

11. Over Eating: The Prophet (PBUH) has said, "The heart throws away wisdom if stomach is too full". [11, Vol.2, Page 119].

12. Quarrel and Dispute: Hadrat Ali (A.S.) has said, "One who quarrels more, he becomes blind to truth and reality" [1, Vol.5, H 8115, Page 230].

Allama Majlesi (RH) defining quarrel and dispute says that quarrel means argument and objection on others without religious aim. If so, these are considered dangers of knowledge because aim of such discourse is personal benefit and proof of personal superiority and not to establish Truth or to refuge falsehood. This results in diversion from right path [7, Vol.7, Page 399 and 400].

The Prophet (PBUH) considered hell as dwelling place for such people:

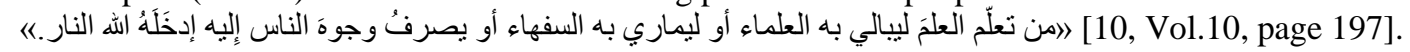

"If one acquires knowledge to show his superiority to others and unnecessarily evolve in discourses, God will send him to the fire of hell."

These examples relating to curse and danger of knowledge have been drawn from sayings of great religious leaders. A person, only by removing these hurdles can enjoy fruits of knowledge and use these for benefit and promotion of humanity, otherwise knowledge and learning is a curse and leads to darkness and problems.

\section{Conclusion}

The above mentioned descriptions are a few direct and indirect spiritual aspects of knowledge and wisdom which have been derived from ahadith. If the subject is thoroughly studied and detailed research is carried out, we may be able to bring out many more aspects, desirable and useful. Some spiritual results are attained immediately by stepping into the realm of knowledge, e.g. man becomes loved one of God, is respected by angels and they spread their wings for the seeker of knowledge and God ensures livelihood for knowledge seekers. All pray for such a person and a knowledge seekers dies in the course of his efforts, he becomes martyred. One should know that this relates to the knowledge which is for God, for knowing The Truth and for serving creatures of God.

\section{Acknowledgment}

This research is a grant-based research supported by Payame Noor University, Iran. 


\section{References}

[1] A . Altamimi, Qorar Al hekam WA Dorar Al kalam, Tehran University publication, 1987.

[2] H. Al Harrani, Tohaf Al 'oqul, Qom Islamic Publications, affiliated to Jame-a-Modarreseen, 1995.

[3] M. R. Hakimi, , Al hayat, Tehran, the Islamic culture publication office.

[4] M. Koleini, Osoul Kafi, Tehran Dar Al Kotob Al Islamia, 1983.

[5] M. Mohammadi Nik (Rey Shahri), Seema-e-Elmo-Hekmat,Qom Dar Qoran -Darul Hadith,1983.

[6] R. Khomeini, Jehad-e-Akbar, publication, Moassasae Tanzeem-o-Nashr-e-Aathar-e-Emam Khomlini Qom, 1995.

[7] M.B. Majlesi, Behar Al Anwar, Qom Dar Al Kotob Al Islamia, 1983

[8] A. Fahd, Helli, al-Daye, Qom vejdani Al Islami publication, 1983.

[9] A.H. Deilami, Qom Moassasa-e-Aale Beit, 1988

[10] H. Hindi, , Kanz Al Ommal, Tehran Dar Al Kotob Al Islamia ,1989.

[11] H. Al Halwani, , Nozhat Al nazer WA Tanbi Al khater Halwani, Qom Alhadi publication, 1988. 